\title{
平面壁上の有限幅直立平板まわりの流れ*
}

\author{
岡 本 史 紀 $^{* 1}$, 小林 正 人*2, 門野司*3 \\ 加賀谷 春幸*4, 島 根 淳*4
}

\section{Flow past Flat a Plate of Finite Width Placed Vertically on a Ground Plane}

\author{
Shiki OKAMOTO*5, Masato KOBAYASHI, Tsukasa KADONO, \\ Haruyuki KAGAYA and Atsushi SHIMANE \\ ${ }^{* 5}$ Department of Mechanical Engineering Shibaura Institute of Technology, \\ 3-9-14 Shibaura, Minato-ku, Tokyo, 108-8548 Japan
}

\begin{abstract}
This paper describes the flow past a flat plate of finite width placed vertically on a ground plane. The experiment was carried out in an $800 \mathrm{~mm}$ diammeter Eiffel type wind tunnel with a working section of $1.5 \mathrm{~m}$ length and mainly at Reynolds number of $5.1 \times 10^{4}$. The surface pressure distributions on the flat plate and on the ground plane around the flat plate were measured, and the drag coefficient was determined from them. The vortices generated in the flow field around a flat plate have also been observed by flow-visualization. Furthermore the time mean velocity in the flow field behind the flat plate was measured by use of a laser Doppler velocimeter. Consequently, it is found that the disappearance of shedding arch vortices is in the range of $W / H=4 \sim 7$, while the drag coefficient attains minimum near $W / H=5$.
\end{abstract}

Key Words: Pressure Distribution, Vortex, LDV, Velocity Distribution, Flow Visualization, Separation, Flat Plate, Finite Width

\section{1. 緒言}

近年, 環境問題に関連して建築物, 土盛りされた高 速道路, または防音へい等の二次元模型についての風 洞実験がしばしば行われている.この種の二次元平板 の実験的研究としては, 平面壁上の境界層厚さと直立 平板の高さの比率を変えたGood-Joubert ${ }^{(1)}$, 坂本 ら(2)の研究があげられる.しかし実際に多く見られ る防風フェンス, 航空機のスポイラなどは平板でも有 限幅であるため, その周辺の流れは平面壁上の二次元 平板の結果をそのまま用いることはできない.このよ うな有限幅の三次元平板では平板側面から背後への流 れ込みが存在するため, 平板上方から背後への流れ込 みのみしか存在しない二次元平板とは周辺の流れ特性 は大きく異なることが予想されるからである.

従来, 三次元物体まわりの流れは構造設計または環 境問題から重視され, 有限長円柱 ${ }^{(3)}$, 有限長角柱 ${ }^{(4)}$, 円 すい ${ }^{(5)}$, 球 ${ }^{(6)}$, 半球柱体 ${ }^{(7)}$ など多くの形状の研究がす

* 原稿受付 2004 年 12 月 20 日.

*1 正員, 芝浦工業大学工学部 (- 108-8548 東京都港区芝浦 39-14).

*2 キヤノンファインテック(株).

*3 准員, (株)本田技術研究所栃木研究所.

*4 学生員, 芝浦工業大学大学院工学研究科.

E-mail : okamoto@ sic.shibaura-it.ac.jp
でに報告されている.しかしながらおのおのの形状に ついても比較的単純な有限幅平板の場合についてさ え, 限られた内容の報告しかされていない. 坂本ら ${ }^{(8)}$ は有限幅平板の平板高さに対する平板幅の比，すなわ ち平板の有限幅比をパラメータとして, 系統的に渦生 成のようすを調べ, カルマン渦の生成限界は有限幅比 が 0.8 付近で, それを境にしてカルマン渦からアーチ 渦へと生成渦の形態移行を明らかにした。 その後, 岡 本 ${ }^{(9)}$ はアーチ渦の生成に関して有限幅比が 1 の正方 形平板からはアーチ渦が生成されることを明らかにし た。しかしながらフェンスやスポイラなどに見られる 有限幅比 1 以上となる平板の場合ではアーチ渦生成と 消滅など, アーチ渦の生成限界となる有限幅比, およ びアーチ渦消滅前後での平板まわりの流れの変化など の報告は見当たらない. 他方, 坂本ら ${ }^{(10)}$ は平板の有 限幅比の増減によって平板の表面圧力, 抗力係数が変 化し, 特に有限幅比が 5 付近で抗力係数は最小值に達 することを報告した. しかし，この抗力係数の有限幅 比 5 付近の変化と流れ特性の関連については言及され ていない.

本研究ではこれらに関連して, 有限幅直立平板の有 限幅比をパラメータとして, 一様流中の有限幅直立平 板まわりのアーチ渦生成のようすを可視化観察し,ア 
一チ渦消滅のメカニズム, 生成限界および限界付近で の有限幅直立平板の表面圧力, 抗力係数, 平面壁上の フローパターン, 近傍後流の変化の詳細について実験 的に明らかにする.

\section{記 号}

$C_{D}$ : 平均抗力係数

$$
=\int_{0}^{1} \int_{-0.5}^{0.5}\left(C_{P 1}-C_{P 2}\right) d(Y / W) d(Z / H)
$$

$C_{P}$ : 圧力係数 $=\left(P-P_{S \infty}\right) /(1 / 2) \rho U_{\infty}^{2}$

$C_{P 1}, C_{P 2}$ : 平板前面, 背面圧力係数

$H:$ 平板高さ

$n:$ 振動数

$P:$ 静圧

$P_{S \infty}:$ 主流の静圧

$R e:$ イイルズ数 $=H U_{\infty} / \nu$

$U:$ 時間平均速度

$U_{\infty}:$ 主流速度

$W:$ 平板幅

$X, Y, Z:$ 平板の前面底面中央を原点とする直角座標 軸, 流れ方向に $X$ 軸, 水平方向に $Y$ 軸, 鉛 直方向に $Z$ 軸をとる

$x$ : 平面壁上前縁から流れ方向の距離

$\nu:$ 空気の動粘性係数

$\rho:$ 空気密度

\section{2. 実験装置および実験方法}

本実験では表面圧力測定, レーザ・ドップラー流速 計による速度測定, 流れの可視化観察に際して 3 種類 の実験装置を用いた。 まず表面圧力測定や平板まわり の流れの実験に使用した風洞は吹出し口直径が 800 $\mathrm{mm}$ の Eiffel 形風洞で測定部の長さは $1500 \mathrm{~mm}$ であ る. 地面板として幅 $1000 \mathrm{~mm}$, 長さ $1500 \mathrm{~mm}$, 厚さ $4 \mathrm{~mm}$ のアルミニウム板を用い, その前縁は前縁はく 離を防ぐため流線形に削り, 図 1 に示すように風洞吹 出し口底面から上方に離して取付けた. 平板の取付位 置は前縁から $500 \mathrm{~mm}$ 下流のところである. 平板の 取付位置における境界層特性を表 1 に示す。この実験 では境界層厚さに対する平板の高さの割合は $H / \delta=$ 4.81 である. 平板の幾何学的形状は高さ $H=50 \mathrm{~mm}$, 有限幅比 $W / H=0.5,1,2,4,7,10$ の 6 種類に変え実験 を行った. 平板の表面圧力, 地面板上の平板まわりの 静圧の測定には精密微差圧計を用いた. 実験は主流速 度 $U_{\infty}=15 \mathrm{~m} / \mathrm{s}$ 付近とし, 平板高さを代表長さにとる とレイノルズ数 $R e=H U_{\infty} / \nu=5.1 \times 10^{4}$ のもとで行っ た.
Table 1 Boundary layer

\begin{tabular}{|ll|l|}
\hline Boundary layer thickness & $\delta(\mathrm{mm})$ & 10.4 \\
\hline Momentum thickness & $\theta(\mathrm{mm})$ & 1.13 \\
\hline Displacement thickness & $\delta^{*}(\mathrm{~mm})$ & 1.46 \\
\hline Shape factor & $H^{*}$ & 1.30 \\
\hline$H / \delta$ & & 4.81 \\
\hline
\end{tabular}

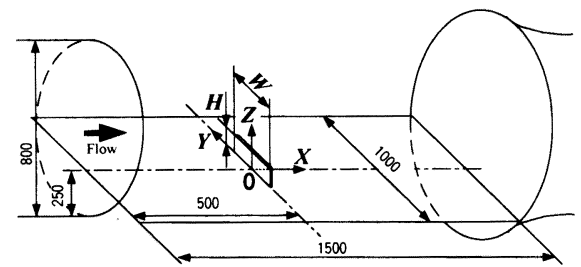

Fig. 1 Scheme of apparatus and nomenclature

次にレーザ・ドップラー流速計による実験に使用し た風洞は $200 \mathrm{~mm} \times 200 \mathrm{~mm}$ の正方形断面をもつ循環 形風洞で測定部の長さは $2000 \mathrm{~mm}$ である.平板はノ ズル出口から $530 \mathrm{~mm}$ 下流の位置に設置した。平板 の幾何学的形状は高さ $H=15 \mathrm{~mm}$, 有限幅比 $W / H=$ $2,4,7$ の 3 種類に変え, 実験を行った。実験では平板 まわりの流れを中心として, 平均速度の測定には二次 元レーザ・ドップラー流速計を用いた．実験に用いた ドップラー流速計の諸元は次のようである. 前方散乱 形, デュアルビームモード ( 2 カラー 4 ビーム法), 最 大出力 $4 \mathrm{~W}$ (測定時の出力 $300 \mathrm{~mW}$ ), アルゴン・イオ ンレーザ(波長：緑 $514.5 \mathrm{~nm}$, 青 $488 \mathrm{~nm}$ ), ビーム間 隔 $50 \mathrm{~mm}$, 収束レンズ焦点距離 $500 \mathrm{~mm}$, ビーム交差 部測定体積最大直径緑 $0.16 \mathrm{~mm}$, 青 $0.16 \mathrm{~mm}$, 長さ 緑 $3.2 \mathrm{~mm}$, 青 $3.0 \mathrm{~mm}$, シーディングには線香の煙 を用いた．実験は主流速度 $U_{\infty}=10 \mathrm{~m} / \mathrm{s}$ とし,レイノ ルズ数 $R e=H U_{\infty} / \nu=9.92 \times 10^{3}$ のもとで行った. 最 後に流れの可視化観察の実験に使用した回流水槽は幅 $400 \mathrm{~mm}$, 深さ $300 \mathrm{~mm}$, 測定部の長さ $1000 \mathrm{~mm}$ であ る. 平板の幾何学的形状は $H=30 \mathrm{~mm}$, 縦横比 $W / H$ $=2,4,7$ の 3 種類に変え, 実験は速度 $U_{\infty}=3 \mathrm{~cm} / \mathrm{s}$, $R e=8.96 \times 10^{2}$ のもとで行った.ここで 3 種類の実験 装置を用いた実験では実験条件としてレイノルズ数が 異なっているが, 本実験のレイノルズ数の範囲では, 平板まわりの流れは一般に平板の抗力係数の変化に見 られるように, レイノルズ数に依存しないことが知ら れている. 特に, 流れの可視化観察の実験では平板ま わりの流れの定性的変化を調べるために行ったもので あり, レイノルズ数の違いについてもその点で配慮し た. 


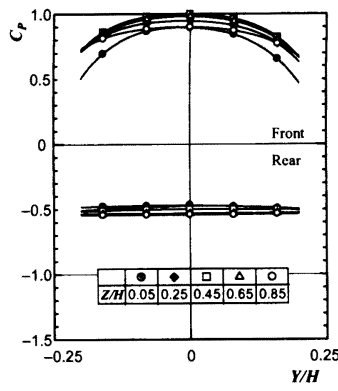

(a) $W / H=0.5$

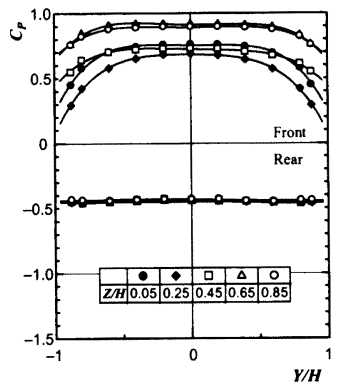

(c) $W / H=2$

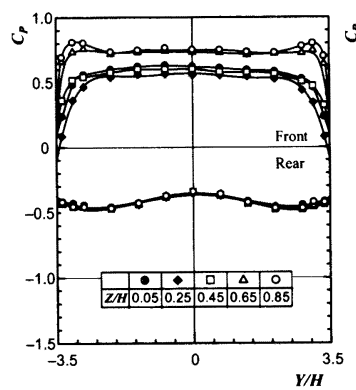

(e) $W / H=7$

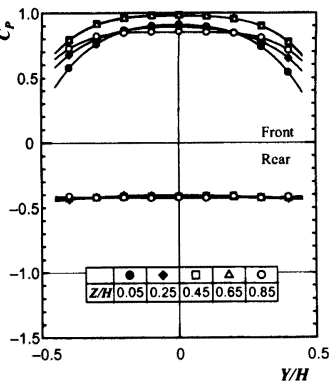

(b) $W / H=1$

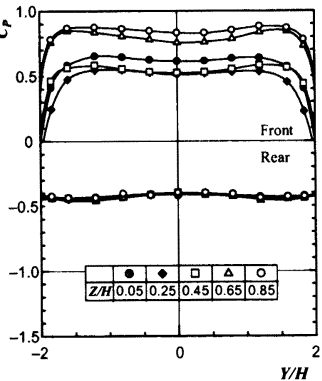

(d) $W / H=4$

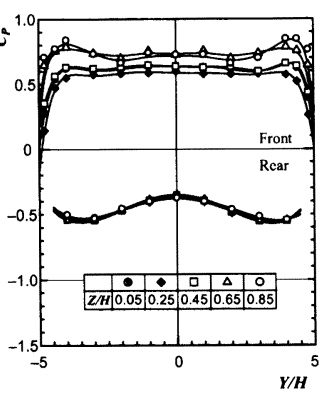

(f) $W / H=10$
Fig. 2 Surface pressure distribution on flat plate

\section{3. 実験結果および考察}

$3 \cdot 1$ 平板表面圧力分布 平板の前面と背面の圧 力分布を図 2 に示す. 図 2 より平板前面における圧力 分布は, $W / H$ の変化によってかなり異なる.すなわ ち $W / H=0.5,1$ の場合, 圧力分布は, 平板の中心線上 $(Y / H=0)$ で最大となるが, $W / H=4$ を超えると平板 の両側端付近以外でほぼスパン方向にフラットな分布 を示している.また, 平板上部 $(Z / H=0.85,0.65)$ と 下部 $(Z / H=0.45,0.25,0.05)$ では少し異なった分布に なっていることが見てとれる.このように $W / H$ が大 きくなるにしたがって, 圧力分布がしだいにフラット になるのは, $W / H$ の増加とともに平板両側端付近を 除いて, 圧力分布において $Y$ 方向に変化しない二次 元的部分が現れるためである.また $W / H=0.5,1$ 以 外の平板では平板上流前方より平板上端，および両側 端へ向かう流れの傾向が強まり, 相対的に平板正面に 向かう流れが弱まるために中心部の圧力が $C_{P}=1$ に ならない.

一方, 背面における圧力は $W / H=0.5$ から $W / H=$ 10 まで, $Z / H$ の違いによる変化はほとんど見られな い.また，W/Hが大きくなり，W/H=7からはスパ ン方向に変化が生じ, 圧力の最小值となる位置は, $W / H=7$ のときは $Y / H= \pm 2.5, W / H=10$ のときは $Y / H= \pm 3.5$ というように有限幅比が増加するに伴い スパン方向に離れていく，つまり，W/Hが小さい場 合では，流出する渦はすでに報告されているように(8) 平板左右両側端からはく離する縦渦と平板上端からは く離する横渦とが一体になっているアーチ渦のため背 面圧力分布もスパン方向にほぼ一定であるが，W/H が増加し平板左右両側端からの縦渦がスパン方向に離

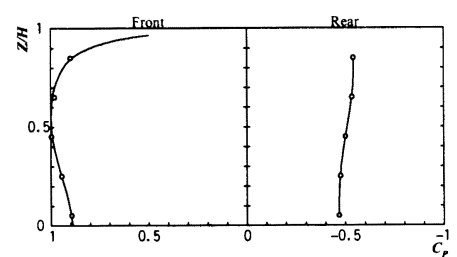

(a) $W / H=0.5$

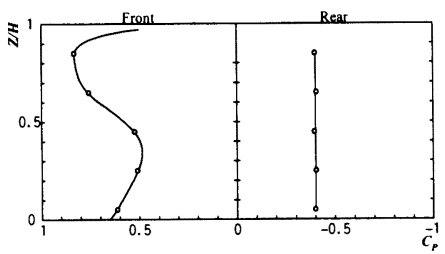

(d) $W / H=4$

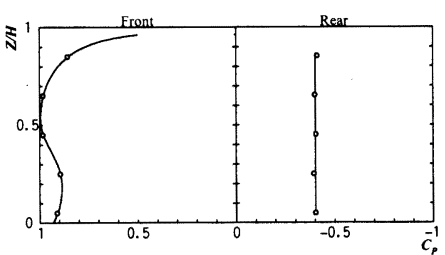

(b) $W / H=1$

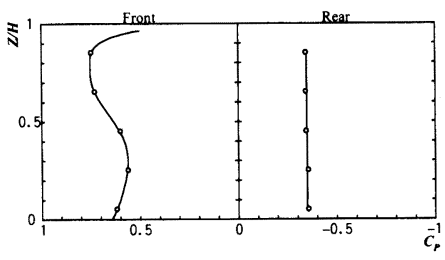

(e ) $W / H=7$

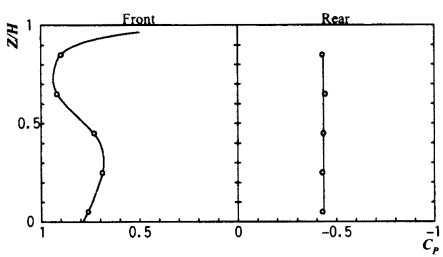

(c) $W / H=2$

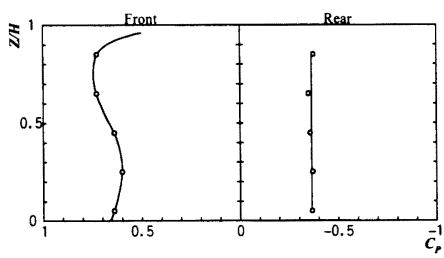

( f ) $W / H=10$

Fig. 3 Surface pressure on flat plate at $Y / H=0$ 


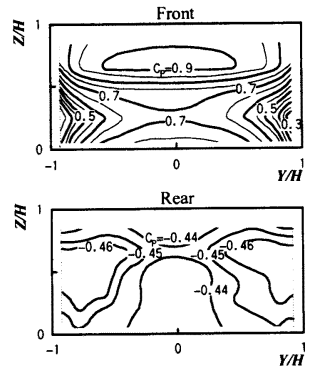

(a) $W / H=2$

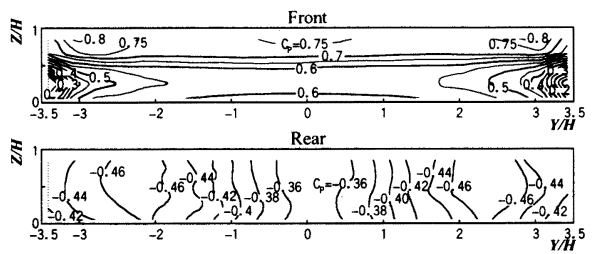

(c) $W / H=7$
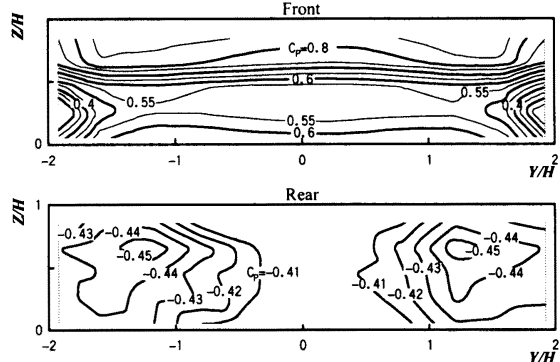

(b) $W / H=4$

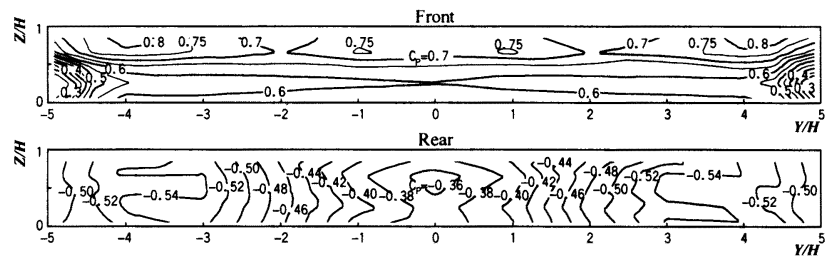

(d) $W / H=10$

Fig. 4 Surface pressure distribution on flat plate $(Z / H=0.05 \sim 0.85)$

れると, 平板上端からはく離した横渦との一体性は崩 れ, 背面圧力分布もスパン方向に大きく変化する.

$Y / H=0$ における前面ならびに背面の圧力分布を図 3 に示す. 図 3 の平板前面の圧力分布を見ると, 最大 圧力点は $W / H=1$ においては, $Z / H \fallingdotseq 0.55$ である. しかし，W/H の増加に伴い最大圧力に達する高さ方 向位置 $Z / H$ も先に述べた平板上流側より平面壁上か らはく離した流れが, 平板上端へ向かうために, 平板 上端に近づいていく，また，平板上端では，圧力が低 くなっている. 一方, 平板背面の圧力分布を見ると $W / H$ の值にかかわらず, $C_{P}=-0.4$ 前後の值である.

図 4 に平板の前面ならびに背面の等静圧線図を示 す. 前面では $W / H=2$ の場合は中心付近で圧力が高 くなる分布形であるが, $W / H$ が 4 を超えると $W / H=$ 10 までは平板の両側端付近でははく離の影響が顕著 に現れ，それ以外ではスパン方向の圧力差が小さくほ ぼ同様な分布形で，平板側端の影響が中心まで及ばな くなることが見てとれる.一方，背面では圧力は前面 と比べて変化は少なく, $W / H=1$ の場合を除くと $W / H$ が増加するとスパン方向の圧力変化が大きくな ることがわかる．特に $W / H$ が 2 を超すと, 平面両側 端からはく離した縦渦に関係する平板背面における圧 力が最も低くなる位置は, ほぼ左右対称の 2 箇所にあ り，その位置は $W / H$ が増加するに伴いスパン方向に 離れている。

$3 \cdot 2$ 抗力係数 平板に働く平均抗力係数は表面 圧力から求められる。ここで求めた抗力は厳密にいえ
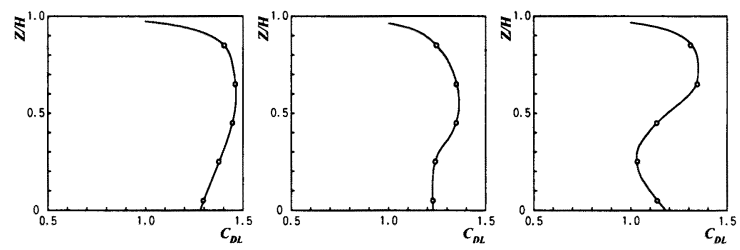

(a) $W / H=0.5$

(b) $W / H=1$

(c) $W / H=2$
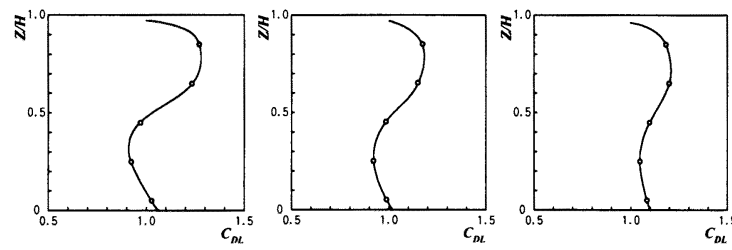

(d) $W / H=4$ (f) $W / H=10$

Fig. 5 Local drag coefficient

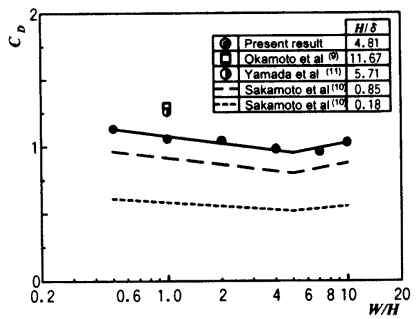

Fig. 6 Drag coefficient 
ば圧力抗力であるが，近似的に全抗力と見られる。図 5 には測定した平板前面および背面圧力から求めた局 所抗力係数 $C_{D_{L}}$ 宗す. 平均抗力係数 $C_{D}$ の変化を図 6 亿示す。図6には岡本 ${ }^{(9)}$, 坂本 ${ }^{(10)}$, および山田(11)の 結果を同時に示した。

図 5 から $W / H=0.5,1$ と $W / H=2,4,7,1002$ 種 類に大きく局所抗力係数の分布形は分けられる. $W / H=0.5,10$ 場合は, 局所抗力係数は高さ方向にお ける変化は少ないが, $W / H=2,4,7$ の場合は平板前面 の圧力分布と同樣に高さ方向に打ける変化は大きく， 平板上方に局所的に大きな力が作用していることがす かる、しかし，その傾向は $W / H=10$ になると二次元 平板の結果(1) と同様に少なくなるようである。

図60平均抗力係数では本結果注，坂本 ${ }^{(10)}$ の結果

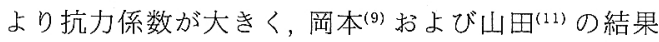
より小さい。この平均抗力係数の差異は坂本ら ${ }^{(10)}$ が 指摘したように平板高さと境界層厚さの比 $H / \delta$ 挐 いに起因する。図 6 から明らかなように各縦横比の平 板における抗力係数 $C_{D}$ は $H / \delta$ の值によって異なっ ており，かつ $W / H$ が大きくなるにしたがってしだい に減少し，W/H=5.0を超えると再び増加している。 このように $W / H$ の増加に伴って抗力係数 $C_{D}$ が減少 するのは，前述した圧力分布から明らかなように平板 の前面における圧力が，W/H が大きくなるにしたが い, 減少することに起因する。また，W/Hが $5.0 を$ 超えると $C_{D}$ が増加するのは，前面に扔ける圧力が $W / H$ にってあまり差異はないが, 背面における圧 力は平板下流に流出する渦の影響を強く受け，その結 果両側端付近の背面圧が低下するためであると思われ る.

\section{$3 \cdot 3$ 平面壁上の平板まわりのフローパターン}

図 7 は歯磨き粉の溶液を用い表面塗布法によって可視 化した平面壁上の平板まわりのフローパターンを示 す。平板の上流側手前にははく離線がはっきりと現 れ，その内側には馬てい形渦が生じる. $W / H=1 \sim 4$ の場合には，平板を大きく取り囲さように馬てい形渦 の存在を示すはく離線が，明りょうに現れているが， $W / H=7,10$ の場合には平板前面中央付近では馬てい 形洞の形跡は消滅しているようである。その点を詳細 に調べると, 平板前面中心付近に扔いて流れ方向に沿 って多数の細かいしまが平板に向かって見えるが，こ れは流線が急激に上方へ曲げられ，流れがZ方向に 立ち上がっているあとが，多数の細かいしまとして現 れていると考える.さらにこれは $W / H=7,10$ の平板 前面圧力分布で，両側端付近の圧力より中央付近の圧 力が低くなる部分と一致しており，側端より平板中央

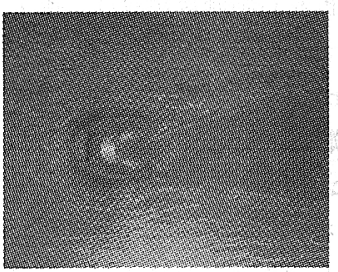

(a) $W / H=1$

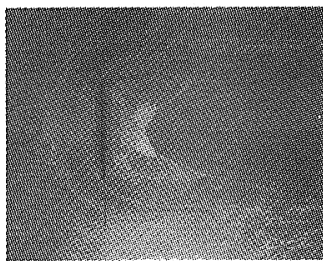

(c) $W / H=4$

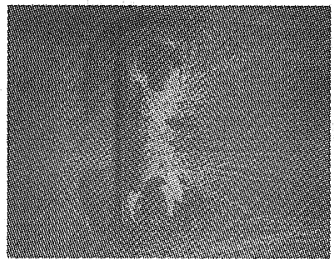

(e) $W / H=10$

Fig. 7 Flow pattern around flat plate on ground plane

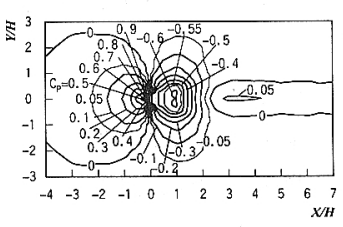

(a) $W / H=0.5$

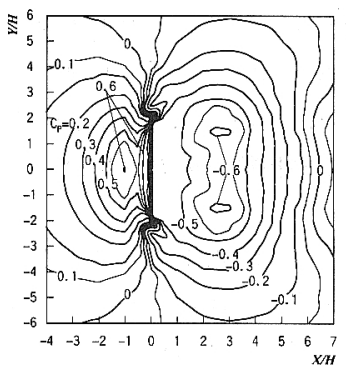

(c) $W / H=$

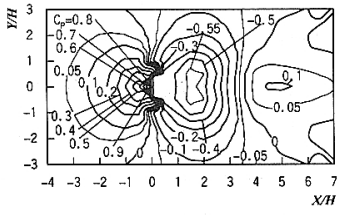

(b) $W / H=1$

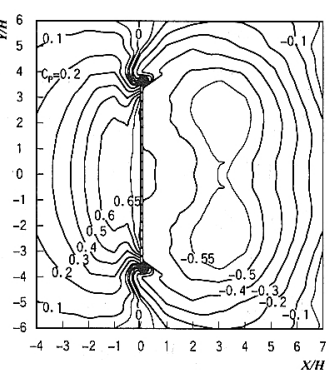

(d) $W / H=7$
Fig. 8 Surface pressure distribution on ground plane

付近に近づく流線の方向が急激に上方へ曲げられ，そ の結果, 平板前面圧力分布において中央付近の圧力が 側端付近の圧力より低くなったものである。どの. $W / H$ の值においても平板の後方に一対の白い粉だま 
りが確認できる.これは平板左右両側端からはく離す る縦渦の下端部である。この, 粉だまりの位置は $W / H$ が増加するにしたがってスパン方向に離れてい る.このように平板両側端からはく離した縦渦が $W / H$ の増加とともにスパン方向に離れるために平板 の背面圧力がこの渦の影響を強く受け, その結果とし て平板背面圧力分布で述べたように圧力がスパン方向 に大きく変化する。

図 8 は $W / H=0.5,1,4,7$ の平板まわりの平面壁上 の等静圧線図を示す.どの場合でもスパン方向に対称 な位置に閉じた等圧線で示される一対の最小圧力領域 が見られる.これは可視化写真における粉だまりの位 置に相当し, 平板両側端からはく離した縦渦の下端部 に当たる. $W / H=1$ の場合はこの渦は平板上端から はく離した横渦と一体となるアーチ渦を形成し,これ らの根元の位置を軸として, $W / H$ が大きい値のため 先端からの強いダウンウォッシュによってアーチ渦は 斜めに傾き倒され，下流に流出する．この一対の負圧 領域(縦渦の下端部) は, $W / H=1$ に比べ $W / H$ が 4 か ら 7 へ増すとスパン方向に離れていく.また平板の上 流側では $W / H$ が増すにつれ, 平板のかなり前方より 圧力上昇が始まり，その結果等静圧線図の分布形も異 なってくる.

$3 \cdot 4$ アーチ渦の生成と消隇 平面壁上の有限幅 平板まわりの流れ場においては次のような 2 種類の渦 が存在する.

（1）平板と平面壁との接続領域に発生する渦

（2）平板の端からのはく離流によって発生する渦 平面壁上の平板近くのはく離線の内側に馬てい形渦 が生じ，この渦は平板前方から両側をまわり，流れ方 向に軸をもち下流へ流れる。著者の岡本 ${ }^{(9)}$ は回流水 槽を用いて，インキ流しの方法によって可視化観察を 行い, $W / H=1$ の平板の場合について馬てい形渦の存 在を示した。この馬てい形渦の外側では吹上げ, 内側 では吹下ろしがあり,これが平板後方のダウンウォッ シュを強める原因である。

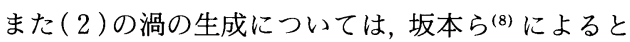
平板後方に生成される渦の形態は, 非対称形いわゆる カルマン渦形と対称形いわゆるアーチ渦形の二つの夕 イプに大別され, $W / H=0.8$ 程度までは非対称形, $W / H=0.8$ を超えると対称形となることが報告され ている. 本実験では, 大半が $W / H=0.8$ を超えた場 合であるが, 有限幅比が大きくなると平板上端からの はく離した横渦の強さがしだいに大きくなり，その結 果上端からのはく離した横渦と両側端からはく離した 縦渦が一体となるアーチ渦となって対称形で下流に流
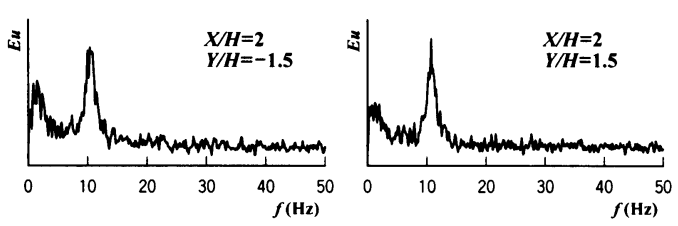

(a) $W / H=2$
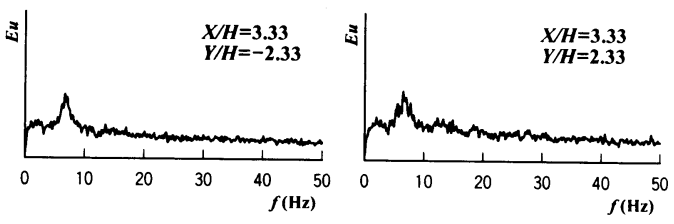

(b) $W / H=4$

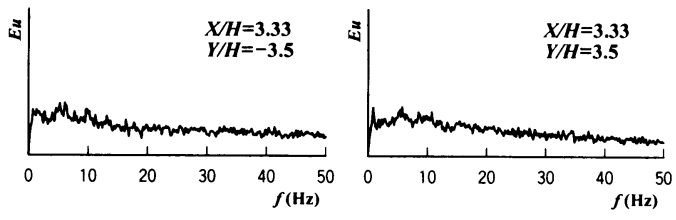

(c) $W / H=7$

Fig. 9 Power spectra at $Z / H=0.33$

出する.一方, $W / H$ が 0.8 より 小さい場合では, 平 板上端からはく離した横渦が平板両側端からはく離し た縦渦に比べて弱く，縦渦が支配的になるために，非 対称形のカルマン渦となり下流に流出する.さらに無 限幅平板 (二次元平板) になると, 平板上端からのはく 離した横渦だけとなり, 流れは平板の後方の平面壁上 に再付着し, 一つの安定した渦領域を形成し, 有限幅 平板とは背面近傍の流れはまったく異なったものとな る.

ここで, 有限幅平板から流出する渦の存在を調べる ために, $W / H=2,4,7$ の平板の場合について平板の左 右側端後方の $X / H=2$ および 3.33 の位置での熱線流 速計で測定した速度変動の $X$ 方向成分のパワースぺ クトルを図 9 に示す.パワースペクトルは流出渦の振 動数に相当する周波数で鋭いピークをもつことが知ら れている(3).したがってパワースペクトル曲線におい てピークの存在の有無は周期的な流出渦の有無を意味 する.

図 9 を見ると ( a ), ( b )の $W / H=2,4$ の場合には ピークの存在が確認され, 平板両側端から渦の流出が 明らかであるが, ( c )の $W / H=7$ の場合になると, ピ ークの存在が消滅し, 周期的な渦の流出がないことが 示されている. 図 $9(\mathrm{a})$, （b )の $W / H=2,4$ の場合, 先に述べた $W / H=0.8$ を超える範囲であるため, ア 一チ渦が生成されていることが考えられるが，これを 


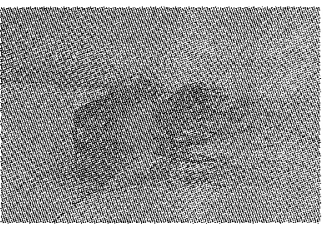

(a) $W / H=2$

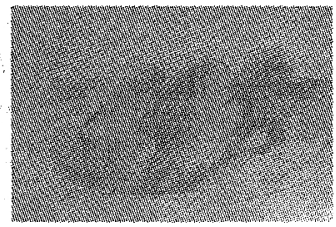

(b) $W / H=4$

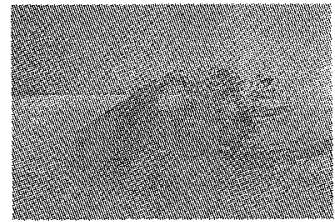

(c) $W / H=7$

Fig. 10 Flow visualization

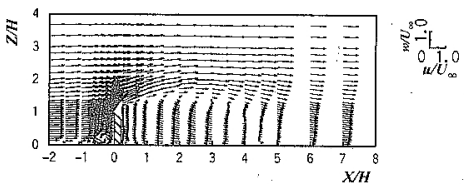

(a) $W / H=2$

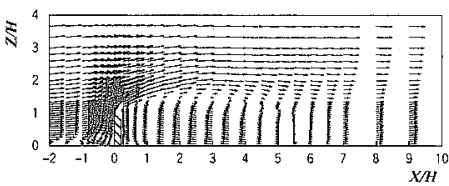

(b) $W / H=4$

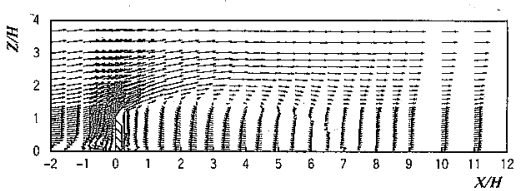

(c) $W / H=7$

Fig. 11 Velocity vector at $Y / H=0$

回流水槽においてメチレンブルー水溶液を用いた注入 トレーサ法により可視化観察を行い確認した。図 10 は $W / H=2,4,7$ の平板から流出する渦のようすを後 方斜め上方より撮影した写真を示す。 $W / H=2,40$ 平板では，平板の上端，㑡端から流れは同時にはく離 し，はく離した縦渦と横渦が一体となるアーチ渦が生 成され，周期的に下流へ流出するようすが確認され た。一方, 図 $10(\mathrm{c}) 0 W / H=7$ の場合では平板の上 端，側端から同時にはく離するが，平板上端からはく 離した横渦が支配的となるために一体となるにく離渦 は生成されず，崩れ消隇する。これ挝図 $10(\mathrm{a}) ，(\mathrm{~b})$ の $W / H=2,4$ の場合と比較して平板側端からのはく

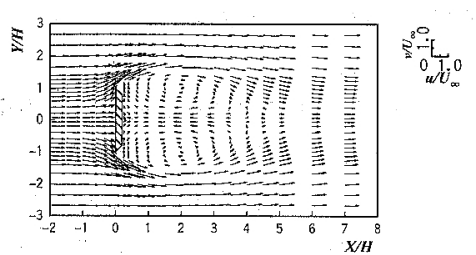

(a) $W / H=2$

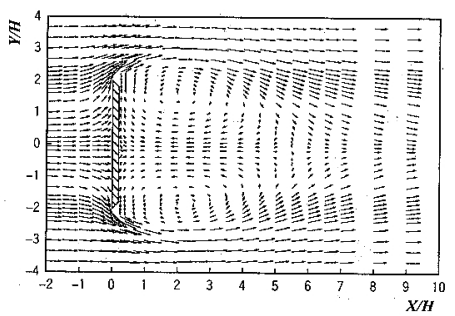

(b) $: W / H=4$

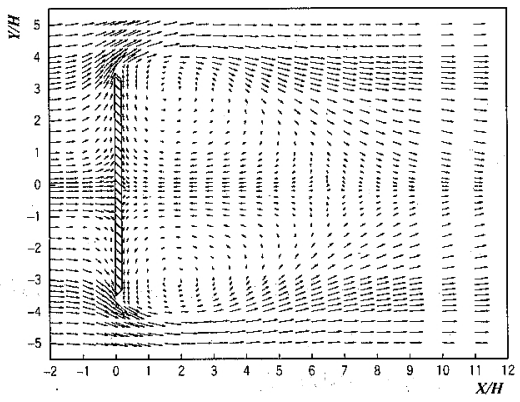

(c) $W / H=7$

Fig. 12 Velocity vector at $Z / H=0.5$

離した縦渦が平板上端からはく離した横渦に比べ弱 く，画渦の合体。成長によってア一チ渦が崩れ消滅す ることを示している。以上の結果より $W / H=2,40$ 場合は，アーチ渦が流出し，W/H=7の場合になると， アーチ淍は消滅することが明らかになり，W/H=4 〜7がアーチ滑生成の限界箇囲であることがわかっ te.

$3 \circ 5$ 平面壁上の有限幅平板まわりの流れ 平面 壁上の有限幅平板まわりの流れのようすを調べるた め, 中央部 $(Y / H=0) に$ にる鉛直断面での速度べク トルの分布を図 11 に示す。図 11 より平板先端から離 れた流線は(a)の $W / H=2 て ゙ は X / H=4.5$ （b）の $W / H=4$ では $X / H=5.7$, (c)の $W / H=7$ では $X / H$ $=6.8$ 付近の下流でおの扔の平面壁上に再付着し，こ の流線で囲まれた内側に再循環領域が形成される。二 次元平板の場合には平板先端から離れた流線流 $X / H$ $=13$ 付近の下流で平面壁上に再付着する(1)ことを併 せて考学ると，平板幅が増すにつれて再循環領域は流 れ方向に拡大することが明らかである。また平板前面 
上流平面壁付近には馬てい形渦の存在を示す小さい再 循環領域が見られる。

次に近傍後流の水平面における下流方向への変化を 調べるために, 図 $12 に Z / H=0.5$ の水平断面におけ る速度ベクトル線図を示す。速度べクトルより平板ま わりの流れは左右の側端よりはく離した流れが平板背 後に逆流域を含み大きな再循環領域が形成されている ことが明らかである。この $Z / H=0.5$ の水平断面で は, 再循環領域は図 11 ( a )の $W / H=2$ では $4 \leqq X / H$ $\leqq 4.5$ ，（b ）の $W / H=4$ では $5 \leqq X / H \leqq 5.5$ （c ）の $W / H=7$ では $6 \leqq X / H \leqq 6.5$ の範囲で終了する.さら に平板背後の再循環領域には左右一対の大きい循環領 域が存在し，その循環領域の中心は平面壁上では図 7 に示した一対の白い粉だまりの位置, さらに図 8 に示 した一対の最小圧力領域の位置にほぼ相当する.

\section{4. 結 論}

本研究によって得られた結果を要約すれば次のとお りである。

（1）有限幅平板の表面圧力は平板両側端からはく 離する緹渦によって大きく影響する，平板の有限幅比 が増すにつれ，縦渦の下端部と思われる一対の最小圧 力領域はスパン方向に離れ，それによって背面圧力も スパン方向に変化が現れる.

（2）有限幅平板に働く抗力係数は平板の有限幅比 が増すにつれ減少し, 平板幅 $W / H=5$ 付近で最小と なり，それを超えると再び増加する。

(3) $W / H=2,4$ の有限幅平板では平板上端から はく離した横渦と両側端からはく離した縦渦が一体と なるアーチ渦が生成され，下流へ流出するが， $W / H=$ 7 の有限幅平板では平板両側端からはく離した縦渦が 平板上端からはく離した横渦に比べ弱く, 横渦が支配
的となり両渦の合体・成長によってアーチ渦が, 崩れ 消滅する. したがって $W / H=4 \sim 7$ の範囲内にアーチ 渦の生成限界があり,アーチ渦生成と消滅が上記 (2) の抗力係数の増減に密接に関係する。

（4）有限幅平板の後方には再循環領域が形成され るが, 平板の有限幅比が増すにつれて, その領域は流 れ方向に拡大する。

\section{文献}

(1) Good, M. C. and Joubert, P. N., The Form Drag of Two-Dimensional Bluff-Plates Immersed in Turbulent Boundary Layers, J. Fluid Mech., 31-3 (1968), 547-582.

（2）坂本弘志・森谷優・有江幹男，乱流境界層内におかれた 鈍い物体周辺の流れに関する研究(第 1 報, 垂直平板の抗 力), 機論, 41-342, B(1975), 526-535.

（3）岡本史紀, 平面壁上の有限長円柱を過ぎる流れ，日本航 空宇宙学会誌, 36-414 (1988), 343-350.

（4）岡本史紀・松永勝秀, 平面壁上の有限長角柱まわりの流 れ, 機論, 55-512, B (1989), 1091-1096.

(5) Okamoto, S., Turbulent shear flow behind a sphere placed on a plane boundary, Turbulent Shear Flows, 2 (1980), 246-256, Springer-Verlag.

（6）岡本哲史・八木田幹・片岡真一，平板上に置かれた円す いまわりの流れ，機論, 42-359, B(1976)，2107-2115.

( 7 ) Okamoto, S., Turbulent shear flow behind hemispherecylinder placed on ground plane, Turbulent Shear Flows, 3 (1982), 171-185, Springer-Verlag.

（8）坂本弘志・有江幹男・森谷優 - 谷口清一, 乱流境界層内 に埋没する有限幅平板周辺の流れ(第 2 報, ストローハル 数およびフローパターン), 機論, 48-433, B(1982), 1683-1691.

（9）岡本史紀，平面上の正方形断面をもつ鈍い物体を過ぎる 流れの実験的研究, 機論, 50-457, B(1984)，2068-2076.

（10）坂本弘志 - 有江幹男 - 森谷優 - 谷口清一, 乱流境界層内 に埋没する有限幅平板周辺の流れ(第 1 報, 平板に作用す る圧力および抗力)，機論，48-433，B(1982)，1674-1682.

（11）山田英巳 - 大坂英雄 - 影山芳郎・古屋雅啓, 平面壁上に 直立する有限幅多孔平板まわりの流れ(第 1 報, アスペク 卜比が1の多孔平板の場合), 機論, 53-490, B(1987), 1696-1703. 